Note

\section{Interaction of Benzaldehyde to the Membrane Protein of Escherichia coli}

\author{
Kenji SaKaguchi,* Tokichi Miyakawa* \\ Setsuo TAKeUCHI, ** Kuniko NaKagaWA** \\ and Eiji HAYASE** \\ *Laboratory of Microbiological Chemistry, \\ Mitsubishi-Kasei Institute of Life Sciences, \\ Machida-shi, Tokyo, 194, Japan \\ **Institute of Physical and Chemical Sciences, \\ Wako-shi, Saitama, 35I, Japan \\ Received March 13, 1979
}

A carcinostatic principle was isolated from the fig homogenate and identified as benzaldehyde. ${ }^{1 \sim 3)}$ During the purification process, the active principle was assayed by its two biological activities; one is the enhancement of the incorporation of labeled tryptophan into Escherichia coli cells and the other is the carcinostatic activity against AC755 cancer implanted in mice. The both activities paralleled completely, and these two activities are commonly comprehensible from the view point of interaction of benzaldehyde with membrane proteins. ${ }^{1)} \quad$ The uptake of ${ }^{14} \mathrm{C}$-labeled tryptophan into E. coli was enhanced to the extent of $20 \sim 60 \%$ by the addition of benzaldehyde $0.1 \sim 0.001 \mu \mathrm{g} / \mathrm{ml}$, while the incorporation of glutamic acid, alanine, thymine and adenine decreased to $70 \%$ of its original uptake (Table I). Colistin, which is a natural surface active agent, consistently inhibited the incorporation of the amino acids and organic bases tested probably because of its destructing effect to the cell membrane. The efficiency of benzaldehyde at low concentration is noteworthy because the increase of its concentration to $10 \mu \mathrm{g} / \mathrm{ml}$ or more in the incorporation experiments have resulted in the loss on both enhancing and decreasing effect.

The change of incorporation efficiency is apprehensible by the change of biomembrane which includes active transport system of amino acids and bases. Therefore, the attachment of labeled benzaldehyde on the E. coli cell membrane was studied. The exponentially growing cells were harvested, suspended in the cold mineral-glucose medium, ${ }^{4)}$ added with ${ }^{14} \mathrm{C}$-benzaldehyde $3.75 \mu \mathrm{Ci} / \mathrm{nmol} / \mathrm{ml}$ and chloramphenicol $40 \mu \mathrm{g} /$ $\mathrm{ml}$ and incubated $15 \mathrm{~min}$, at $37^{\circ} \mathrm{C}$, and washed three times with distilled water. The cells thus treated adsorbed about $1 \%$ of labeled benzaldehyde inoculated. The outer-membrane fraction and cytoplasmic membrane fraction were separated from the burst protoplasts after Mizushima and Yamada. ${ }^{5}$ ) The radioactivity remained only on the slower sedimenting peak consisted with cytoplasmic membrane of E. coli cells (Fig. 1). The separation of two membrane fractions were assigned by the test of succinate dehydrogenase activity. ${ }^{6)}$

In order to study further the selective binding of labeled benzaldehyde to the cell-membrane proteins, the isolated outer and cytoplasmic membrane fractions were incubated in a phosphate buffer containing ${ }^{14} \mathrm{C}$-benzaldehyde $20 \mu \mathrm{Ci}$ per $\mathrm{ml}$, washed, and electrophoresed by a slab acrylamide gel of discontinuous system. ${ }^{7}$ Figure 2 shows that the interaction of benzaldehyde with the membrane protein is not uniform but some proteins selectively bound with the aldehyde. Even some protein bands did not bind with the adduct at all. The

Table I. Effect of Benzaldehyde to the Uptake of Amono Acids AND BASES INTO $E$. coli Cells

\begin{tabular}{lccccc}
\hline \multirow{2}{*}{ Substrate } & \multicolumn{4}{c}{ Amount incorporated (cpm/\%) } \\
\cline { 3 - 6 } & Control & Colistin & \multicolumn{3}{c}{ Benzaldehyde } \\
\cline { 5 - 6 } & & $5 \mu \mathrm{g} / \mathrm{ml}$ & $0.1 \mu \mathrm{g} / \mathrm{ml}$ & $0.01 \mu \mathrm{g} / \mathrm{ml}$ & $0.001 \mu \mathrm{g} / \mathrm{ml}$ \\
\hline Thymine & $2028 / 100$ & $333 / 16$ & $1399 / 69$ & $1566 / 77$ & $1891 / 93$ \\
Adenine & $4433 / 100$ & $420 / 9$ & $3135 / 71$ & $3684 / 83$ & $4246 / 96$ \\
Glutamic acid & $4067 / 100$ & $0 / 0$ & $2842 / 70$ & $2779 / 68$ & $3203 / 79$ \\
Alanine & $6072 / 100$ & $468 / 8$ & $5283 / 87$ & $5438 / 90$ & $5838 / 96$ \\
Tryptophan $^{13}$ & $680 / 100$ & $0 / 0$ & $1076 / 158$ & $915 / 134$ & $808 / 119$ \\
\hline
\end{tabular}

The exponentially growing $E$. coli $\mathrm{W} 3110$ cells were harvested, washed with the cold $0.05 \mathrm{M}$ Tris$\mathrm{HCl}$ buffer $\mathrm{pH} 7.35$, suspended in a mineral-glucose medium $\left(\mathrm{CM}\right.$ medium) ${ }^{4}$, containing glucose $0.2 \%$, chloramphenicol $40 \mu \mathrm{g} / \mathrm{ml}$ and ${ }^{14} \mathrm{C}$-labeled substrates $0.1 \mathrm{Ci}$ per $4.9 \times 10^{-5} \mathrm{mmol}$ per $\mathrm{ml}$, incubated for 30 min with shaking, and the radioactivity incorporated into the cells was counted on the membrane filter after harvesting and washing with the cold mineral-glucose medium. ${ }^{1,5}$ )

The incorporation of labeled substrates into $E$. coli cells at $30 \mathrm{~min}$ incubation were represented by $\mathrm{cpm}$ value and by percentage to the control experiments. 


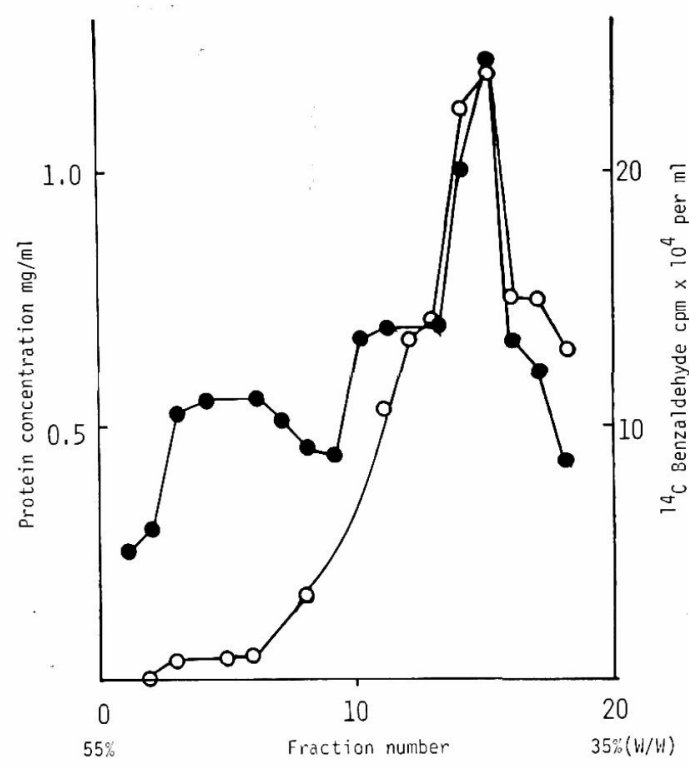

Fig. 1. Binding of ${ }^{14} \mathrm{C}$-Benzaldehyde to the Membrane Fraction of $E$. coli Cells.

The membrane fraction of $E$. coli cells treated with ${ }^{14} \mathrm{C}$-benzaldehyde were analysed by the sucrose density gradient from $55 \%$ to $35 \%(\mathrm{w} / \mathrm{w})$, and the protein concentration of each fraction was determined by Folin's phenol reagent. ${ }^{6} \quad$ The cpm was assayed by a scintillation counter.

$\mathrm{O}, \mathrm{cpm}$ of ${ }^{14} \mathrm{C}$ benzaldehyde; $\bullet$, protein concentration.

protein from cytoplasmic membrane retained much more amount of benzaldehyde compared to the outermembrane protein. However, the latter also bound a small amount of the compound which probably resulted from the conformation change of the isolated membrane.

The aldehydes are known to form Schiff base aducts with free amino or sulfhydryl groups in the protein molecule. ${ }^{8)}$ Benzaldehyde and other aldehydes have been reported to enhance the ability of oxygen binding on sickle haemoglobin molecule. ${ }^{\text {g) }}$ They inhibit the $\mathrm{Na}^{+}$- and $\mathrm{K}^{+}$-activated, $\mathrm{Mg}^{++}$dependent ATPase, which is a typical membrane protein. ${ }^{10)}$

The binding of benzaldehyde with the cytoplasmic and outer membrane protein of $E$. coli cells can be a possible elucidation why the benzaldehyde can affect to the incorporation ratio of substrates into the cell, because the membrane proteins are known to play major roles for the transportation of substrates. Another possibility is the inclusion of benzaldehyde into the lipid layer of cell membrane causing the change of permeability of the membrane, however, we have not found much amount of labeled benzaldehyde in outermembrane fractions which of course contain much lipids.

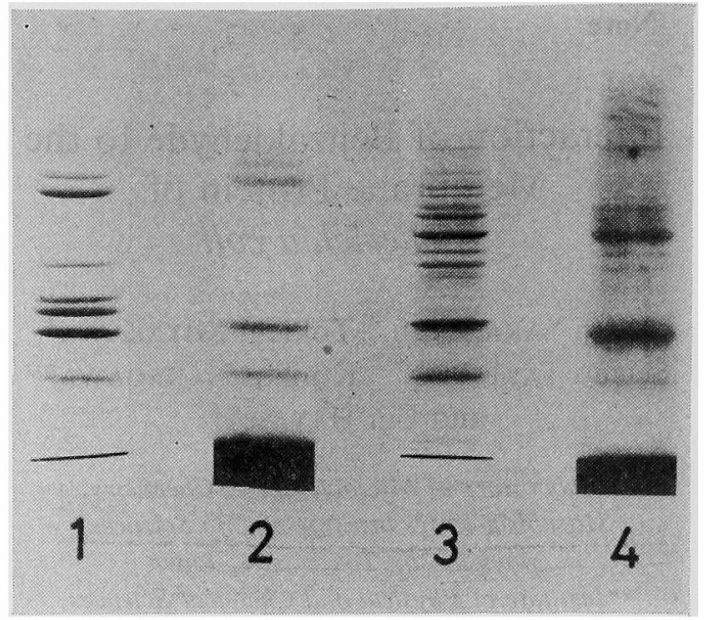

FIG. 2. Covalent Labeling of Membrane Proteins with ${ }^{14} \mathrm{C}$-Benzaldehyde.

To $1 \mathrm{ml}$ of each suspension of isolated outer- and cytoplasmic membrane ( $300 \mu \mathrm{g}$ protein) in $50 \mathrm{~mm}$ sodium phosphate buffer $\mathrm{pH} 7.4,20 \mu \mathrm{Ci}$ of [carbonyl ${ }^{14} \mathrm{C}$ ] benzaldehyde (specific radioactivity $3.96 \mathrm{mCi}$ / mmol, Amersham) was added, incubated for $30 \mathrm{~min}$ at $37^{\circ} \mathrm{C}$. With $9 \mathrm{ml}$ of $50 \mathrm{~mm}$ sodium phosphate buffer ( $\mathrm{pH}$ 7.4) the suspensions were centrifuged at $12,000 \times g$ for $30 \mathrm{~min}$ at $4^{\circ} \mathrm{C}$, and washed twice. The pellet was solubilized by heating at $100^{\circ} \mathrm{C}$ for 1 minute in a $0.5 \mathrm{ml}$ of buffer containing $62.5 \mathrm{~mm}$ Tris, $3 \%$ SDS, $1 \% \beta$-mercaptoethanol and $10 \%$ sucrose, $\mathrm{pH}$ 6.8. One hundred $\mu \mathrm{l}$ of samples was subjected to SDSpolyacrylamide gel electrophoresis ( $7.5 \%$ acrylamide). The gel was stained with Coomassie brilliant blue. The fluorogram was prepared after Bonner and laskey. ${ }^{12)} \quad 1$, Coomassie blue stained outer membrane proteins; $2,{ }^{14} \mathrm{C}$-benzaldehyde labeled outer-membrane proteins; 3 , Coomassie blue stained cytoplasmic membrane proteins; $4,{ }^{14} \mathrm{C}$-benzaldehyde labeled cytoplasmic membrane proteins.

Benzaldehyde, a periactin, has been reported to be effective for the treatment of patients with various types of cancers. ${ }^{1,2)}$ The authors (T. M. and K.S.) also found the selective cytotoxicity of this substance and its derivatives ${ }^{11)}$ against $\mathrm{SV}-40$ virus transformed cultured rat fibrobalst cells and not to the normal fibroblast cells, at the concentration of 10-50 $\mu \mathrm{g}$ per ml culture medium through the attachtment of the substances to the cell surface protein. ${ }^{3)}$

We thank to Prof. S. Mizushima of Nagoya University for discussions and for supplying $E$. coli membrane preparations.

\section{REFERENCES}

1) S. Takeuchi, M. Kochi, K. Sakaguchi, K. Naka- 
gawa and T. Mizutani, Agric. Biol. Chem., 42, 1449 (1978).

2) M. Kochi, S. Takeuchi and T. Mizutani, Abstract of XIIth International Cancer Congress, $5 \sim 11$ October, 1978.

3) T. Miyakawa, J-L. Zundel and K. Sakaguchi, Proceedings of 51 st Meeting of Japan Biochemical Society, 1978, p. 696.

4) Y. Anraku, J. Biol. Chem., 242, 793 (1967).

5) K. Sakaguchi and K. Ishikawa, Annual Report of Mitsubishi-Kasei Institute of Life Sciences, Vol. 1, $1971 \sim 1972$, p. 14.

6) S. Mizushima and H. Yamada, Biochim. Bio- phys. Acta, 375, 44 (1975).

7) V. K. Laemmli, Nature, 277, 680 (1970).

8) R. H. Zaugg, J. A. Walder and I. M. Klotz, J. Biol. Chem., 252, 8542 (1977).

9) V. G. Erwin, J. Kim and D. Anderson, Biochem. Pharmacol., 24, 2089 (1975).

10) L. A. Manson, "Biomembranes," Vol. VIII, Plenum Press, New York and London, 1976.

11) J-L. Zundel, T. Miyakawa and K. Sakaguchi, Agric. Biol. Chem., 42, 2191 (1978).

12) W. M. Bonner and R. A. Laskey, Eur. J. Biochem., 46, 83 (1974). 